\title{
マグネシウム結晶における疲労き裂伝播過程*1
}

\author{
安藤 新二 岩元暢 宏*2 堀 $\quad$ 隆之*2 頓田英機
}

熊本大学工学部知能生産システム工学科

J. Japan Inst. Metals, Vol. 65, No. 3 (2001), pp. 187-190

(C) 2001 The Japan Institute of Metals

\section{Fatigue Crack Propagation in Magnesium Crystals}

Shinji Ando, Nobushiro Iwamoto*2, Takayuki Hori*2 and Hideki Tonda

Department of Mechanical Engineering and Materials Science, Faculty of Engineering, Kumamoto University, Kumamoto 860-8555

The fatigue crack growth behavior of pure magnesium has been investigated in laboratory air at room temperature. Two type of compact specimens were prepared from magnesium polycrystalline ingot, and two type of compact specimens with different notch orientations were also prepared from magnesium single crystal made by the Bridgeman technique. Two types of fatigue crack propagation behavior were observed in the magnesium crystals. When a notch is normal to basal plane, a fatigue crack propagates though zigzag route with many basal slip. In the case of notch parallel to basal plane, a fatigue crack propagates through straight route with $\{10 \overline{1} 2\}$ twin, and the value of $\Delta K_{\text {th }}$ is smaller than that of fatigue crack propagation with basal slip.

(Received November 6, 2000; Accepted February 5, 2001)

Keywords: magnesium, single crystal, fatigue crack, twin, basal slip, stress intensity factor

\section{1. 緒言}

材料に繰り返し応力が作用することにより生じる疲労破壊 は，各種機械構造物における損傷原因の多くを占める．金属 の疲労破壊過程は, き裂の発生, 伝播抢よび最終破壊の 3 段階にわけられるが，損傷許容設計の観点からは，き裂伝播 過程が重要であるといわれている1). したがって材料の疲労 特性の改善には，疲労き裂伝播抵抗を向上させなければなら ないが，そのためには疲労き裂伝播過程を明らかにする必要 がある。これまでfccやbccにおいては，疲労き裂先端で互 いに交差するすべり面に揸いて交互にすべりが活動する slip-off 機構2,3) が提案されている. しかし, hcpに抢ける疲 労き裂伝播機構についてはほとんど知られていない。筆者ら はこれまで, hcp 構造をもつ純チタンに打疲労き裂伝播 機構を調査してきた ${ }^{4-6)}$. その結果, き裂伝播方位により進 展挙動が大きく異なり, 切欠面が $(10 \overline{1} 0)$ もしく $(11 \overline{2} 0)$ に 平行な場合, き裂は $[11 \overline{2} 0]$ に伝播し, き裂先端では主すべ り系である $\{10 \overline{1} 0\}\langle\overline{1} \overline{1} 20\rangle$ 柱面すべりの slip-off 機構によっ てき裂が伝播するが，底面に平行な切欠の場合，き裂先端に おいて $\{10 \overline{1} 2\}$ 双晶変形を伴ってき裂が伝播することなどが わかってきた。

さて近年, 環境問題の観点から, 軽量な材料であるマグネ シウムの利用拡大が注目されている。ここでマグネシウムを 構造部材に使用する場合には, その疲労特性も重要となって くるが，チタンと同様にその詳細については全くわかってい ない。 また hcp では金属ごとに結晶の軸比 $c / a$ が異なり, 活

*1 2000年10月 2 日日本金属学会秋期大会に打いて発表

*2 熊本大学大学院生 (Graduate Student, Kumamoto University)
動するすべり系や双晶系が異なり，マグネシウムの主すべり 系は底面すべりであることから，チタンの疲労き裂伝播挙動 と大きく異なると予想される，そこで本研究では，純マグネ シウム多結晶および単結晶のコンパクト試験片を作成し，疲 労き裂伝播挙動を調査することを目的とした.

\section{2. 実 験 方 法}

作成した試験片の形状および結晶方位を Fig. 1 に示す。 まず純マグネシウムインゴット(純度 99.9 mass \%) から，機 械加工により長さ $L=20 \mathrm{~mm}$, 幅 $W=14 \mathrm{~mm}$, 厚さ $t=7$ $\mathrm{mm}$ の多結晶コンパクト試験片を切り出し, 初期切欠深さ $a_{0}$ が $a_{0} / w=0.35$ となるように, 厚さ $0.3 \mathrm{~mm}$ のダイヤモン

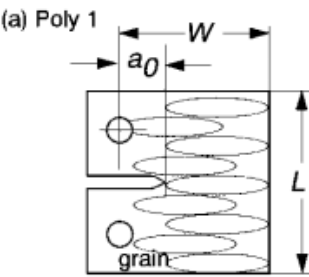

(c) Single

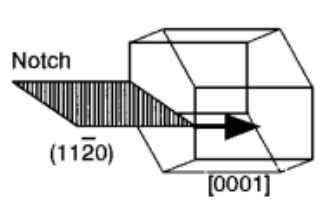

(b) Poly 2

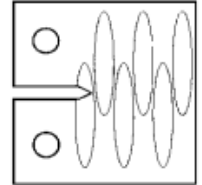

(d) Single 2

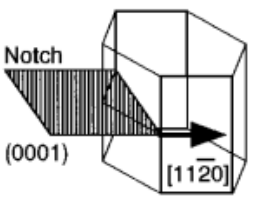

Fig. 1 Orientations of specimens. Notch of (a) Poly 1 and (b) Poly 2 are parallel and normal to grain growth direction, respectively. Notch of (c) Single 1 and (d) Single 2 are normal and parallel to basal plane, respectively. 
ドカッターにより切久を導入した. 多結晶試験片は, 切欠方 向が結晶粒の凝固方向に対して平行な Poly 1 と垂直な Poly 2 の 2 種類とした. 結晶粒の寸法は成長方向で約 $15 \mathrm{~mm}$, 幅が約 $750 \mu \mathrm{m}$ であった．また上記のインゴットから，ブリ ッジマン炉を用いて幅約 $20 \mathrm{~mm}$, 厚さ約 $7 \mathrm{~mm}$ の角柱状の 単結晶を作成した.この単結晶から, 硝酸による無歪切断機 および化学研摩盤により Fig. 1(a) と同形状の単結晶コンパ クト試験片を作成した. 結晶の方位は Fig. 1(c)，(d)に示す ように，切欠面が $(11 \overline{2} 0)$ ，切欠方向が [0001]である Single 1 と，それぞれ(0001)，[112̄0]である Single 2 の 2 種類とし た. 試験片の $L$ および $W$ は多結晶試験片と同じであるが, Single 1 および Single 2 の $t$ はそれぞれ $3 \mathrm{~mm}$ および $6 \mathrm{~mm}$ とし， $a_{0} / w=0.3$ とした. いずれの試料とも加工後, 温度範 囲 $673 \mathrm{~K} \sim 523 \mathrm{~K} ， 1$ サイクル $21.6 \mathrm{ks}$ の熱サイクル焼鈍を 8 サイクル施した.

以上の 4 種類の試験片を, 電気油圧式サーボ試験機 (島津 サーボパルサーEHF-ED5)を用いて, 室温大気中, 応力比 0.1 , 荷重繰り返し周波数 $10 \mathrm{~Hz}$ で, 疲労き裂進展試験を行 った．試験は，切欠から疲労き裂を発生させた後，下限界応 力拡大係数範囲 $\Delta K_{\mathrm{th}}$ 付近まで荷重を徐々に減少させ，その 間に, 一定応力拡大係数範囲 $\Delta K$ での疲労き裂進展速度 $d a$ / $d N$ を, 試験片表面でのき裂長さの測定により求めた。試験 後, 疲労き裂近傍の表面抢よび破面を光学顕微鏡および SEM 観察した.

\section{3. 実 験 結 果}

\section{1 多結晶における疲労き裂進展}

Fig. 2 に各試験片の $d a / d N$ と $\Delta K$ の関係を示す. Poly 1 およびPoly 2 お $\Delta K_{\text {th }}$ はそれぞれ約 $0.8 \mathrm{MPa} \mathrm{m}^{1 / 2}$, 約 1.4 $\mathrm{MPa} \mathrm{m}^{1 / 2}$ となり, Poly 1 は Poly 2 より低い $\Delta K$ でもき裂 が進展する．またPoly 2 の值はばらつきが大きいが， $\Delta K=$ $1.4 \sim 2.0 \mathrm{MPa} \mathrm{m}^{1 / 2}$ の範囲では, $d a / d N$ は Poly 1 の約 30 倍 であり,き裂伝播抵抗は Poly 2 が低い.

Fig. 3 に Poly 1 の表面の疲労き裂進展経路を示す。き裂 は切欠に対しほぼ平行に進展して抢り，主として結晶粒内を 進展している。文部分的に，き裂に対して垂直，もしくは それに近い角度で明瞭なすべり線が形成されており，そのよ うな部分ではき裂が階段状に屈曲して進展していた．次に Poly 2 に打けるき裂進展経路を Fig. 4 に示す，この場合も Poly 1 と同様, き裂は主として結晶粒内を進展しているが, Fig. 4 (a)に示すように，き裂は大きく屈曲している．また き裂が屈曲している部分には多数の明瞭なすべり線があるこ とから，すべり変形がき裂進展に大きく関与していることが わかる. Fig. 4(b)にPoly 2 の裏面を示すが，この場合，き 裂は比較的直線的に進展している．階段状に屈曲した部分に は表面同様にすべり線が見られるが，直線的に進展した部分 には，すべり線ではなく多数の双晶トレースが見られる．こ こでき裂近傍に多数のすべり線が生じた部分の破面を SEM 観察すると, Fig. 5 のように，破面上にはすべり線に対応し て平行な筋模様が形成されており，階段状の破面形態となっ ていた。またこのような破面形態は, 試験片内部の結晶粒に

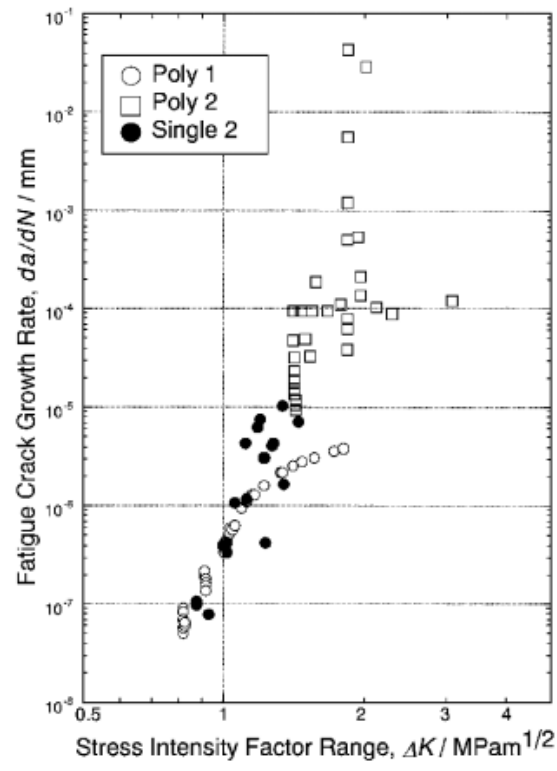

Fig. 2 Fatigue crack growth resistance curves of Poly 1, Poly 2 and Single 2 specimens.

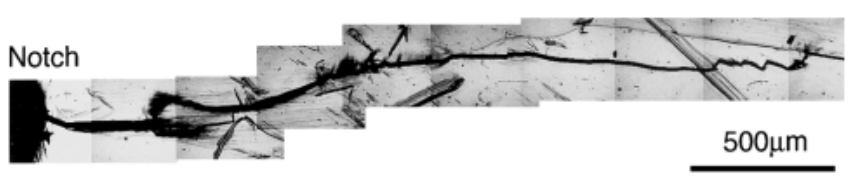

Fig. 3 Crack profile of Poly 1.

おいても多数観察された.

\section{2 単結晶試験片における疲労き裂進展}

Fig. 6 に負荷後の Single 1 の概観を示す. 繰り返し荷重 の上昇に伴い，初期切欠先端々荷重を負荷するためのピン穴 の間で底面すべりが生じ， $\Delta K=0.5 \mathrm{MPa} \mathrm{m}^{1 / 2}$ において， Fig. 6 に示すように大きく開口するのみで, 疲労き裂は発生 しなかった。

Single 2 に打けるき裂進展経路を Fig. 7 に示す．この場 合では，疲労予き裂を入れる段階ではき裂が屈曲している が，その後疲労き裂は直線的に進展した。 またその周囲に は，き裂と平行なすべり線も多少観察されるが，同時に多く の双晶変形が生じている．この Single 2 における $d a / d N-$ $\Delta K$ プロットは, Fig. 2 に示すように, 多少のばらつきがあ るが, Poly 1 の值とほぼ一致している. また Fig. 8 に示す ように, Single 2 の破面上にはき裂進展方向に対して約 60 度 の傾きをもつ双晶バンドが多数形成されている。この双晶バ ンドの角度と, 試験片表面の双晶トレースの角度より, これ らは $\{10 \overline{1} 2\}$ 双晶となる. 破面上の双晶バンド内にはストラ イエーション状の規則的なすじ模様 (Fig. 8(b)) が形成され

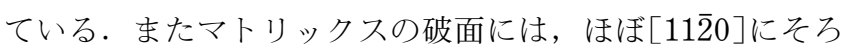
った微小なへき開状ファセットと思われる小さな破面単位が が多数観察される. 

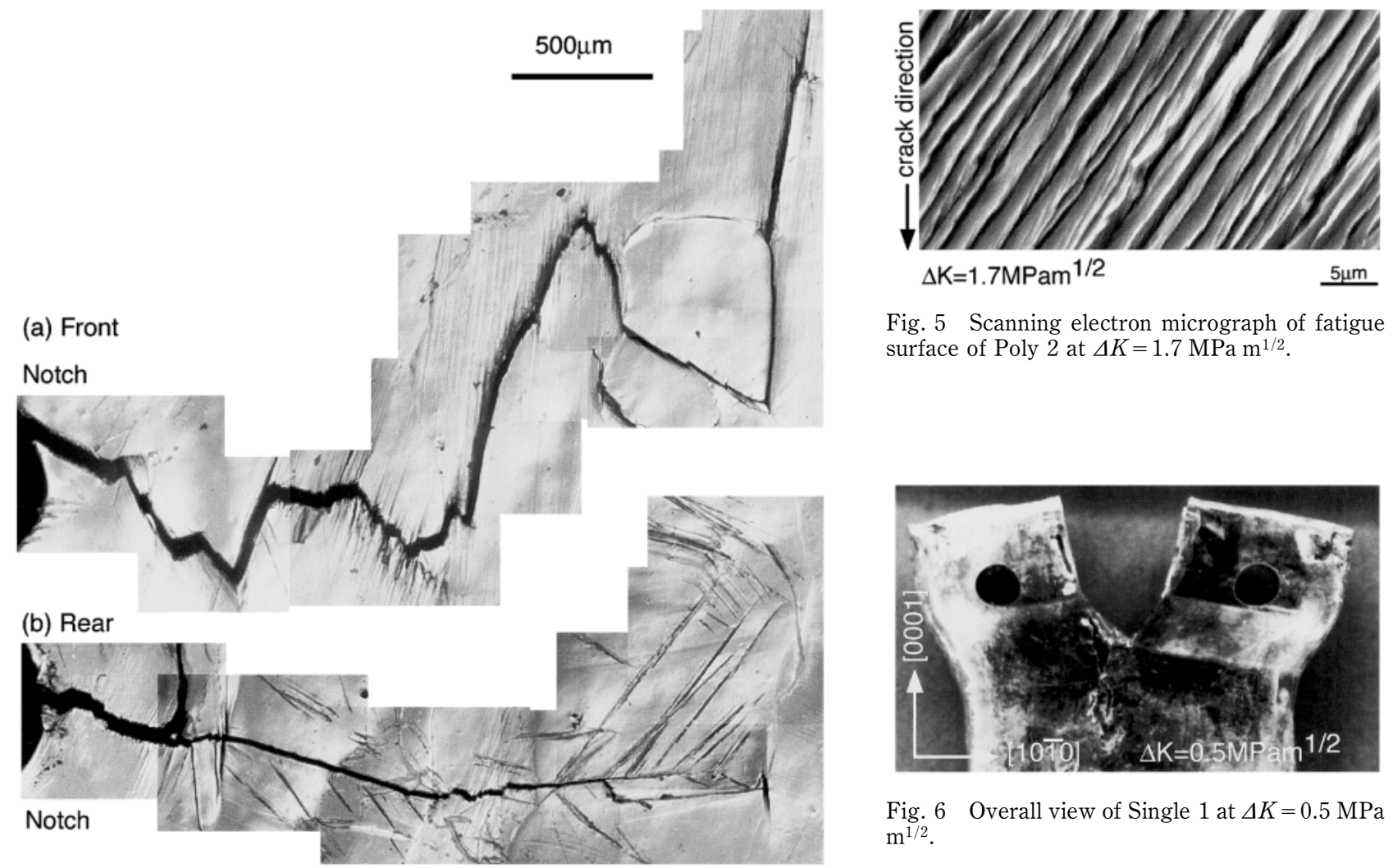

Fig. 5 Scanning electron micrograph of fatigue surface of Poly 2 at $\Delta K=1.7 \mathrm{MPa} \mathrm{m}^{1 / 2}$.

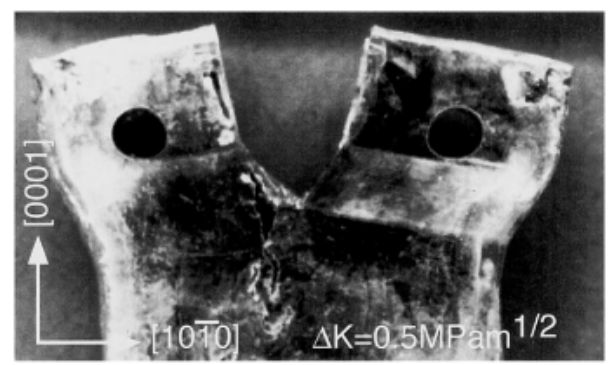

Fig. 6 Overall view of Single 1 at $\Delta K=0.5 \mathrm{MPa}$ $\mathrm{m}^{1 / 2}$.

Fig. 4 Crack profiles of (a) front and (b) rear surface of Poly 2.

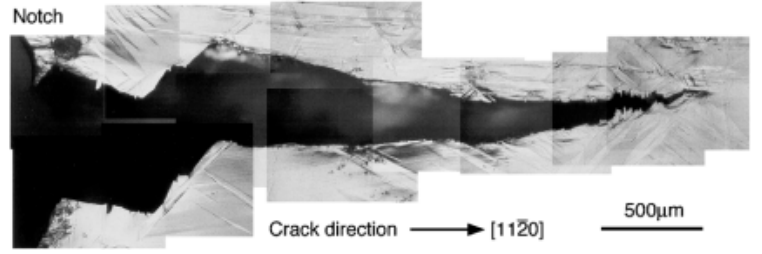

Fig. 7 Crack profiles of Single 2 showing a crack propagated along $[11 \overline{2} 0]$.

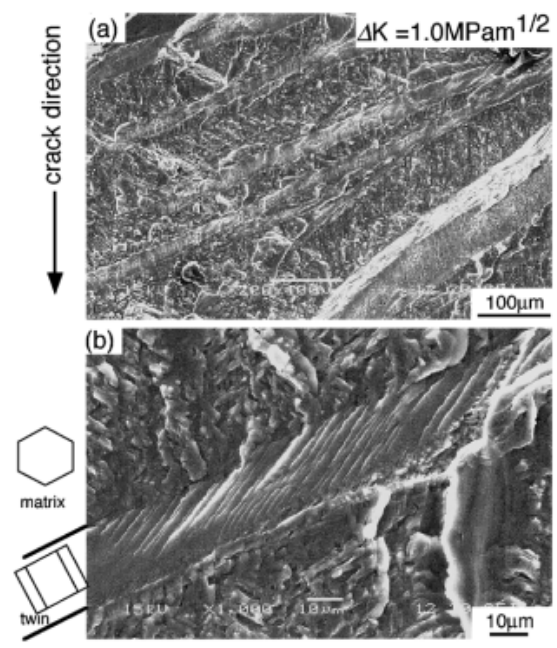

Fig. 8 Scanning electron micrographs of fatigue surface of Single 2. (a) overall view and (b) $\{10 \overline{1} 2\}$ twin and microcleavage-like markings at $\Delta K=1.0 \mathrm{MPa} \mathrm{m}^{1 / 2}$.

\section{4. 考察}

多結晶マグネシウムにおける疲労き裂進展の形態は大きく 2 つにわけられ，1つは多数のすべり線を伴うき裂進展 (Fig. 4(a))であり，もう1つは双晶変形を伴うもの (Fig. 4(b))で ある. 前者においてはき裂は階段状に屈曲しながら進展し, 後者においては直線的なき裂進展となっている.

まずき裂が屈曲して進展する場合について考えてみる。 hcp では，凝固時の結晶粒の優先成長方向は $\langle 10 \overline{1} 0\rangle 7$ である ことから，結晶粒に対して垂直な切欠をもつ Poly 2 では， 切欠面に対し底面が垂直に配向した結晶粒が多数を占めるこ とになる。したがって Single 1 の方位は, その典型的な例 とみなせる。しかし Single 1では底面すべりのみが活動 し，疲労き裂が発生しなかった。これはマグネシウムの底面 すべりの臨界分解せん断応力 CRSS が室温で約 $0.1 \mathrm{MPa}^{8)}$ と 極めて小さく, 低い繰り返し応力でも容易にすべり変形が生 じ，また単結晶では，結晶粒界のようなすべり面上の転位の 運動を抑制するものがなく，すべり変形し続けることができ るためと考えられる．ここで Poly 2 で観察されるすべり線 は，その形態や結晶粒の方位から底面すべりによるものであ るが，多結晶では底面すべりを伴って，き裂が屈曲して進展 する. そこでこの場合のき裂伝進展程として Fig. 9 のよう なモデルを考えた.

繰り返し荷重が作用すると，き裂先端において底面すべり が活動する，底面すべりは極めて低い応力で活動するため, 最初き裂はすべり変形により開口するのみで，その間き裂は 


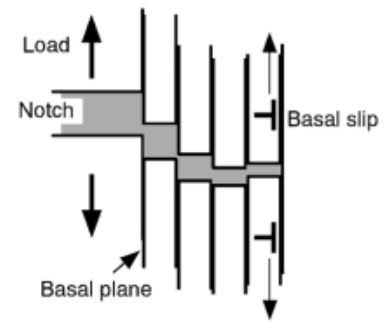

Fig. 9 Schematic figure of fatigue crack propagation normal to basal plane.

進展しない。しかしすべりが繰り返されると，多結晶では結 晶粒界において底面すべり転位が堆積し, 次第と底面でのす ベりが抑制されるようになる，すると底面の前方で，例えば

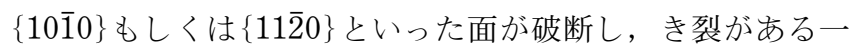
定距離進展し，そこで再び底面すべりが生じることになる． この破断する位置が，き裂前方の位置と必ずしも一致しない ので，これを繰り返すことによりき裂は屈曲しながら進展 し，またその結果，Fig. 5 のような階段状の破面となる. 前 述のようにチタンでは柱面すべりの slip-off が生じるが，マ グネシウムでは底面すべりが容易であり，そのすべり面が 1 つであるため，2つのすべり面が必要な slip-off は起こりに くいといえる.

次に主にPoly 1 および Single 2 において観察された，双 晶変形を伴った直線的なき裂進展について考える．この場 合，き裂近傍にはほとんどすべり線が見られず，底面すべり は起こっていないといえる. 結晶粒に平行に切欠を入れた Poly 1 では，切欠に対して底面が平行に配向した結晶粒が 多いと考えられ，その典型的な例が Single 2 に相当する.

これは Single 2 の $d a / d N-\Delta K$ の関係が Poly 1 とよく一致し ていることからも確認できる。 き裂が底面に平行な場合, 底 面に垂直に引張応力が負荷されても底面すべりは活動できな い．そこでき裂前方で $\{10 \overline{1} 2\}$ 双晶が生じることになる．こ れは麻田ら ${ }^{9)} の c$ 軸に近い方位での引張試験の結果と一致す る.き裂前方で $\{10 \overline{1} 2\}$ 双晶が生じると, Fig. 8(b)に六方晶 の単位胞で示すように，マトリックスに対して双晶バンド内

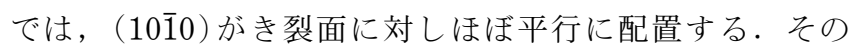
後, き裂が双晶バンドを横切る際に, バンド内にはストライ エーション状の規則的なすじ模様ができたと推察できる。こ のように底面に平行な切欠を導入した場合, き裂進展に伴い
$\{10 \overline{1} 2\}$ 双晶が発生するという点はチタンの場合と一致して いる4-6). チタンでは双晶内では柱面すべりの slip-offによ り疲労き裂が進展するが，マグネシウムの場合のすじ模様の 方位は柱面に平行ではないことから, 柱面すべり以外のすべ り系, 例えば 2 次錐面すべり10) といった非底面すべりが活 動している可能性があるが, 現時点では確定できない. また マトリックスの破面には微小なへき開状のファセットが集合 したような規則性のある模様が観察されるが，この領域にお けるき裂進展機構についてはさらに調査が必要である.

\section{5. 結言}

純マグネシウム多結晶および単結晶のコンパクト試験片を 作成し, 疲労き裂進展挙動を調査し, 以下の結果を得た。

1. マグネシウムの疲労き裂には 2 つ進展形態が見られた.

（1）切欠が底面に垂直に近い方位の場合, 底面すべりを伴 って，階段状に屈曲して疲労き裂が進展する.

（2）切欠が底面に並行な方位の場合， $\{10 \overline{1} 2\}$ 双晶を伴っ て直線的に疲労き裂が進展する。

2. 上記(1)の場合の下限界応力拡大係数 $\Delta K_{\mathrm{th}}$ は約 $1.4 \mathrm{MPa}$ $\mathrm{m}^{1 / 2}$ であり, (2)の場合の約 $0.8 \mathrm{MPa} \mathrm{m}^{1 / 2}$ より高い值となっ た。

\section{文献}

1) P. J. E. Forsyth: Acta Metall. 11 (1963) 703-715.

2) R. M. N. Pelloux: Trans. ASM 62 (1969) 281-285.

3) R. M. N. Pelloux: Eng. Fract. Mech. 1(1970) 697-704.

4) Y. Mine, S. Ando, K. Takashima, H. Tonda and Y. Higo: J. Japan Inst. Metals 61 (1997) 41-48.

5) Y. Mine, S. Ando, K. Takashima, H. Tonda and Y. Higo: J. Japan Inst. Metals 62 (1998) 708-717.

6) Y. Mine, T. Yamada, S. Ando, K. Takashima, H. Tonda, Y. Higo and P. Bowen: Key Engineering Materials 145-149 (1998) 721-726.

7) M. Yamamoto: Kessho Kougaku Handbook, (Kyoritu Shuppan, Japan, 1971) p. 276

8) P. G. Partridge: Metal. Rev. 12 (1967) 169-194.

9) H. Asada and H. Yoshinaga: J. Japan Inst. Metals 23(1959) 649-652.

10) S. Ando, K. Nakamura, K. Takashima and H. Tonda: J. Japan Inst Light Metals 42(1992) 765-771. 